九州大学学術情報リポジトリ

Kyushu University Institutional Repository

\title{
Assessment of Pine Stands Subjected to Industrial Pollution using Ceratocystis laricicola
}

Cho, Nam-Seok

Wood and Paper Science, Chungbuk National University

Pashenova, Natasha V.

Department of Physical and Chemical Biology and Biotechnology of Woody Plants, V. N. Sukachev Institute of Forest SB RAS

Choi, Tae-Ho

Wood and Paper Science, Chungbuk National University

Ohga, Shoji

Laboratory of Forest Resources Management, Division of Forest Ecosphere Management, Department of Forest and Forest Products Sciences, Kyushu Unviversity

https://doi.org/10.5109/12847

出版情報: 九州大学大学院農学研究院紀要. 53 (2)，pp. 395-398，2008-10-28. Faculty of Agriculture, Kyushu University

バージョン：

権利関係 : 


\title{
Assessment of Pine Stands Subjected to Industrial Pollution using Ceratocystis laricicola
}

\section{Nam-Seok $\mathrm{CHO}^{1}$, Natasha V. PASHENOVA ${ }^{2}$, Tae-Ho CHOI ${ }^{1}$ and Shoji OHGA*}

\author{
Laboratory of Forest Resources Management, Division of Forest Ecosphere Management, \\ Department of Forest and Forest Products Sciences, Kyushu University, \\ Sasaguri, Fukuoka 811-2415, Japan \\ (Received June 23, 2008 and accepted July 16, 2008)
}

\begin{abstract}
A method for estimation of tree's condition on activity of defence response in phloem was checked in Pinus sylvestris L. stands located near Krasnoyarsk (Siberia, Russia). The length of necrosis caused by inoculation of phloem of living tree by Ceratocystis laricicola Redf. et Minter was used as the parameter being measured. The field experiments were carried out in two even-aged (about 60 years) pine stands that were approximately equal on structure, productivity, density and recreation loading, but differentiated on degree of industrial pollution. The two permanent sample plots (SP) were founded in the severely polluted stand. The other two SP were placed in the unpolluted pine forest. The amount of pine trees within each SP varied from 200 to 250. From 22 up to 37 pine-trees selected randomly within every SP were inoculated with C. laricicola mycelium (test 1 ) and its extract (test 2). One inoculation hole per one tree (diameter $7 \mathrm{~mm}$ ) was made in stem at a height of $1.3 \mathrm{~m}$. Application of the both agents caused necrosis in phloem around the place of inoculation. In the case of fungal inoculation (test 1), the average length of necrosis in the unpolluted forest exceeded significantly the same parameter in the polluted stand: 51.7-79.4 mm and 39.4-41.3 mm, correspondingly. The action of the fungal metabolites caused the opposite results: in the unpolluted stand the average size of necroses was smaller in comparison with this parameter in the polluted stands $44.5-45.3 \mathrm{~mm}$ and $57.9-61.8 \mathrm{~mm}$. The reasons of this difference are discussed. The both agents (C. laricicola mycelium and its extract) were suitable to reveal the difference of tree's condition in polluted and unpolluted pine stands. The application of fungal extract is more preferable in comparison with fungal mycelium because of smaller variability of necrosis size. Besides, the application of extract allows controlling inoculum dose and excludes the dangerous of spreading infection in forests.
\end{abstract}

\section{INTRODUCTION}

The development of new methods for revealing condition of trees in forests is connected with increasing negative action of industrial pollution on environment. The present methods of estimation of tree's vitality are characterized by some disadvantages, for example, subjectivity of visual evaluation according to different scales, or complexity of model experiments in greenhouses, when physiological parameters are measured in trees subjected to action of toxic substances in gaseous medium (Rozkov and Mikhajlova, 1989).

A new approach of estimation of conifer's condition proposed recently is based on measuring activity of defence response in trees subjected to action of negative ecological factor (Polyakova et al., 2000). The inoculation of phloem with blue stain fungi can be used to induce this tree response. The defence response of conifers to inoculation involves necrosis of phloem in the infested area, impregnating it with phenolics and resin, periderm and callus formation at the periphery of the necrotic lesion (Reid et al., 1967; Wong and Berryman, 1977; Primoz, 1999). The complex of physiological and histological transformations directed on isolation of pathogen within necrotic zone is defined as "hypersensitive reaction" (HR). Eventually, the infecting fungi are

Wood and Paper Science, Chungbuk National University, Cheongju 361-763, Korea

${ }^{2}$ Department of Physical and Chemical Biology and Biotechnology of Woody Plants, V. N. Sukachev Institute of Forest SB RAS, Krasnoyarsk, Russia

* Corresponding author (E-mail: ohga@forest.kyushu-u.ac.jp) enclosed within this reaction zone but under certain conditions may break out and a new periderm is formed (Solheim, 1993). A coincidence of necrosis and infection area boundaries is a characteristic feature of hypersensitivity of host plant to the pathogens (Ozeretskovskaya et al., 1995). It gives an opportunity to use size of necrotic lesion as an indicator of plant's vital capacity. Length of necrotic lesion surrounding site of fungal inoculation and resinosis intensity have been used to estimate the activity of defence response of pine trees to bark beetles (Cook and Hain, 1987).

Application of fungal metabolites instead of living cultures of pathogens is the most attractive method of inducing defence response. Plant defence response induced by pathogen metabolites has been shown in experiments with herbaceous and woody plants (Yang et al., 1989; Ozeretskovskaya et al., 1995). There is some evidence of elicitor-induced defence response in conifers (Miller et al., 1986; Lieutier and Berryman, 1988; Bach and Seitz, 1997). Application of bio-active substances from pathogen mycelium as the inductor of defence response can (1) completely prevent the forests from accidental spreading of fungal infection and (2) solve the problem of inter- and intraspecific variability of pathogen on aggressiveness.

Using artificial inoculation of conifers with blue stain fungi or their metabolites seems to be perspective for development of effective estimation's method though its progress depends on many investigations still. To obtain accurate results the most appropriate fungi or their metabolites have to be selected for every tree species, the optimal doze of inoculum and the most proper HR 
parameter have to be determined.

During preliminary studies the blue stain fungus Ceratocystis laricicola Redf. Et Minter drew our attention by their capability to induce defence response in some tree species. The fungus was isolated from galleries of larch bark beetle (Ips cembrae Heer.) in Siberian larch (Larix sibirica Ledeb.). The beetle can also attack $P$. sylvestris trees, though $C$. laricicola has not been found in tissues of this coniferous species yet (Pashenova et al., 2000). Nevertheless, C. laricicola introduced into $P$. sylvestris living trees and billets has been shown to grow through phloem and sapwood and to produce the evidence of typical defence response (Pashenova et al., 2003). The defence response in phloem of pine trees was observed when the extract of $C$. laricicola mycelium was used as inoculum (Stasova et al., 2003).

The purpose of this work was to check possibility of use $C$. laricicola mycelium and its metabolites for revealing condition of trees in $P$. sylvestris stands subjected to action of air pollution.

\section{MATERIALS AND METHODS}

The sizes of necroses caused by artificial introducing C. laricicola mycelium or its metabolites in phloem of pine trees were studied in polluted and unpolluted stands. The field experiments on inoculation of $P$. sylvestris trees were carried out in two even-aged (about 60 years) pine stands that were approximately equal on such characteristics as structure, productivity, density, recreation loading, but differentiated on degree of industrial pollution. The both stands are located in vicinity Krasnoyarsk that is large industrial city of Siberia (Russia).

The two sample plots (SP1 and SP2) were founded in the stand severely polluted by Krasnoyarsk's plants. This stand was characterized by heavy dust contamination, absence of anthills and green mosses being usual in pine forests. More than $40 \%$ of trees had the chemical burns of needles (up to 20\% of crown). On literature data, surface of pine needles in the stand was polluted with such elements as $\mathrm{Pb}, \mathrm{Cu}, \mathrm{Zn}, \mathrm{Co}, \mathrm{Cr}, \mathrm{Mn}, \mathrm{Sr}, \mathrm{Ni}, \mathrm{F}$, whose total content was 8 times more than that in unpolluted stands (Tatarintsev and Skripalshikova, 2003). The herbaceous plants accumulated from 10 to 100 times more microelements in comparison with healthy forest. Besides, the most toxic pollutant - fluorine was found on the needle surface, and its content was 2-16 times more than that in unpolluted forests (Tatarintsev and Skripalshikova, 2003). The other two plots (SP3 and SP4) were placed in the unpolluted pine forest and presented the control. There were no evidences that antropogeneous factors influenced significantly the unpolluted stand, except the SP4 site, which was undergone a strong ground fire in 1970, whose signs - the fire damage of lower part of trunks marked for a quarter of all trees - were observed till now. The amount of trees within each SP varied from 200 to 250 .

To induce defence response in phloem of pine trees one $C$. laricicola isolate was used in our experiments. The fungus was maintained on $2 \%$ malt extract agar at the temperature $4{ }^{\circ} \mathrm{C}$. C. laricicola mycelium was cultivated on agar and liquid medium with $2 \%$ malt extract at room temperature during 7 and 14 days, correspondingly. The mycelium from agar plates was used without any preparation as inoculum in field experiments. The mycelium from liquid medium was filtered and extracted as it was described recently (Shein et al., 2001).

The field test 1 was carried out from August 2 until September 20, 2002. 36-37 pine trees were selected randomly in each sample plot that provided representative sampling of trees of different size and vigour state. All the trees were inoculated with $C$. laricicola mycelium. The field test 2 was carried out from July 15 until August 14, 2003. In this case, 22-25 trees not involved in the test of the previous year were selected randomly in each sample plot and inoculated with $C$. laricicola extract. The inoculation holes (one per one tree) were made using a 7-mm cork borer into the stem to the sapwood at the height $1.3 \mathrm{~m}$. Small piece of agar with fungal mycelium $(4 \times 4 \times 4 \mathrm{~mm})$ was put into each hole. Water solution of $C$. laricicola extract was injected in amounts of $50 \mu \mathrm{l}$ (400 $\mu \mathrm{g}$ of extract on dry weight) per one hole. After inoculation, each hole was closed by plug of inner bark. After 7 weeks (test 1) and 4 weeks (test 2) outer bark in every site of inoculation was removed and the length of necroses was measured. Comparison of the means of necrosis length was made using Student's t-test with significance level $\mathrm{p} \leq 0.05$.

\section{RESULTS AND DISCUSSION}

Inoculation of pine trees with $C$. laricicola mycelium and extract caused the necroses in phloem. When the $C$. laricicola extract was injected in phloem tissue boundary of necrotic lesions was not well defined but suited for measurement. The histological investigations showed that HR took place in this case too: isolating periderm was formed and phenolics and resin were accumulated in reaction zone (Stasova et al., 2003). As shown in Table 1, which characterizes the results of test 1 , fungal inoculation of trees in the polluted stand caused necroses whose length varied around 41.3 and $39.4 \mathrm{~mm}$ in SP1 and SP2, correspondingly. In the unpolluted stand, the average sizes of necroses were bigger and run to 79.4 and $51.7 \mathrm{~mm}$ in SP3 and SP4, correspondingly. Comparison on Student's test did not confirm significant difference between SP1 and SP2 on average length of necroses, but the both plots in polluted stand differed significantly in this parameter from the two plots in unpolluted forest (Table 1). In addition, the significant difference on average length of necroses was revealed between SP3 and SP4 (the both from unpolluted forest) (Table 1 ).

The contrary results were obtained in test 2 when pine trees were inoculated with $C$. laricicola extract. In this case, the average length of necroses in polluted stand exceeded the same parameter in healthy forest: 61.8 and $57.9 \mathrm{~mm}$ (SP1 and SP2) compared to 45.3 and 
Table 1. Length of phloem necroses caused by C. laricicola mycelium in P. sylvestris trees from polluted and unpolluted forests

\begin{tabular}{|c|c|c|c|c|c|c|c|c|}
\hline \multirow{2}{*}{$\begin{array}{l}\text { Sample } \\
\text { plot }\end{array}$} & \multirow{2}{*}{$\begin{array}{l}\text { Degree of } \\
\text { pollution* }\end{array}$} & \multirow{2}{*}{$\begin{array}{l}\text { Number } \\
\text { of trees }\end{array}$} & \multirow{2}{*}{$\begin{array}{c}\text { Average lesion } \\
\text { length, mm }\end{array}$} & \multirow{2}{*}{ Variability, \% } & \multicolumn{4}{|c|}{ Significance level** } \\
\hline & & & & & SP 1 & SP 2 & SP 3 & $\mathrm{SP} 4$ \\
\hline SP 1 & $\mathrm{p}$ & 36 & 41.3 & 51 & - & - & - & - \\
\hline SP 2 & p & 37 & 39.4 & 38 & 0.65 & - & - & - \\
\hline SP 3 & $\mathrm{u}$ & 36 & 79.4 & 67 & 0.00 & 0.00 & - & - \\
\hline SP 4 & $\mathrm{u}$ & 37 & 51.7 & 47 & 0.05 & 0.01 & 0.01 & - \\
\hline
\end{tabular}

* $\mathrm{p}$ - polluted stand; $\mathrm{u}$ - unpolluted stand

** bold type marks significant differences between means

Table 2. Length of phloem necroses caused by C. laricicola extract in P. sylvestris trees from polluted and unpolluted forests

\begin{tabular}{|c|c|c|c|c|c|c|c|c|}
\hline \multirow{2}{*}{$\begin{array}{l}\text { Sample } \\
\text { plot }\end{array}$} & \multirow{2}{*}{$\begin{array}{l}\text { Degree of } \\
\text { pollution* }\end{array}$} & \multirow{2}{*}{$\begin{array}{l}\text { Number } \\
\text { of trees }\end{array}$} & \multirow{2}{*}{$\begin{array}{l}\text { Average lesion } \\
\text { length, mm }\end{array}$} & \multirow{2}{*}{ Variability, \% } & \multicolumn{4}{|c|}{ Significance level** } \\
\hline & & & & & SP 1 & SP 2 & SP 3 & SP 4 \\
\hline SP 1 & $\mathrm{p}$ & 25 & 61.8 & 45 & - & - & - & - \\
\hline SP 2 & $\mathrm{p}$ & 25 & 57.9 & 40 & 0.59 & - & - & - \\
\hline SP 3 & $\mathrm{u}$ & 22 & 45.3 & 35 & 0.02 & 0.03 & - & - \\
\hline SP 4 & $u$ & 22 & 44.5 & 39 & 0.02 & 0.03 & 0.88 & - \\
\hline
\end{tabular}

* $\mathrm{p}$ - polluted stand; $\mathrm{u}$ - unpolluted stand

** bold type marks significant differences between means

$44.5 \mathrm{~mm}$ (SP3 and SP4) (Table 2). The both plots within polluted stand (SP1 and SP2) did not differ on average size of necroses from each and SP2) did not differ on average size of necroses from each other as well as the two plots from unpolluted stand (SP3 and SP4), but there was difference at high level of significance between polluted and unpolluted plots. It should be also marked decrease of variability of necrosis sizes in test 2 when $C$. laricicola extract was used as inoculum (Table 1, Table 2).

According to our results, the polluted and unpolluted stands differed clearly in the average length of necroses that were induced in phloem of pine trees. The difference appeared after treating both $C$. laricicola mycelium and $C$. laricicola extract. Size of HR-necrosis caused by any infection is believed to depend on tree's vitality (Cook and Hain, 1987) or, what is closely connected, on activity of defence response. Hence, the results obtained in our experiments showed, in principal, the possibility to reveal the difference of tree's vitality and to estimate the changes of this characteristic in different ecological conditions through inducing defence response in trees by artificial introduction of fungal mycelium or its metabolites in plant tissues. Obviously, further developing the method for estimation of tree's condition demands understanding many details, for example, the interrelations between tree and agent provoking defence response. Even in our experiments we faced with contradictory results that need a special explanation.

On the present view, being introduced in tree fungal mycelium begins to grow and extend into surrounding tissues (Wong and Berryman, 1977; Solheim, 1993). It produces metabolites that diffuse, probably, in front of fungal hyphae. The metabolites induce defence response in plant tissues, which is aimed to localizing fungal myc- elium within HR-necrosis (Darvill and Albersheim, 1984). Consequently, the size of necrosis has to depend directly on aggressiveness of fungus and inversely on activity of defence response in tree. Based on the supposition of inhibiting tree's vitality (and thus activity of defence response to infection) by unfavourable ecological factors it should be expected that the length of necroses induced by $C$. laricicola mycelium in the polluted stand had to be bigger than in unpolluted one. Nevertheless, we observed the opposite effect (Table 1).

We are inclined to believe that the reason of such unexpected effect was very strong pollution of sample plots 1 and 2. This unfavourable factor might negatively influence not only pine trees but also growth of $C$. laricicola mycelium in their tissues. Strong pollution of forests has been shown to led to significant decrease of carbohydrate's content in tree tissues (Mykhilova, 1984). Low-molecular carbohydrates are the most common nutritives of ophiostomatoid fungi that cannot easily utilize wood polysaccharides. The low content of simple carbohydrates in phloem could inhibit fungal growth. Besides, fungal growth could be suppressed by toxic substances accumulated in tree's tissues from environment. This supposition is in agreement with the results of the recent phytopathological investigation that showed the low occurrence of infectious diseases (about 2\% of the all trees) in the polluted pine forest where our experiments were carried out (Tatarintsev and Skrypalshikova, 2003).

There was also difference on the average length of necrosis between two sample plots in the unpolluted stand, and SP3 exceeded in this characteristic SP4 (Table 2). As it was mentioned above, SP4 was characterized by the signs of strong fire 30 years ago. We observed the very active resinosis in trees of the sample plot that might inhibit growth of $C$. laricicola mycelium 
in phloem.

The results of test 2 when $C$. laricicola extract was injected in pine trees were more stable and did not conflict with known model of defence response. Fungal metabolites apparently advanced in plant tissues with water and nutritive flows as well as by passive diffusing. This process can be stopped because of chemical modifications of plant cell wall during hypersensitive reaction. Lignin and bound proanthocyanidins take part in strengthening cell wall in the defence response of conifers (Shein et al., 2001). This process leads to formation of impenetrable barrier for fungal metabolites. Increasing size of necroses in polluted stand (SP1 and SP2) could be explained by low activity of defence response in inhibited pine trees. It should be also marked that in the unpolluted stands the low part of necrosis in phloem significantly bigger than upper part of it (57\% against $43 \%$ at $\mathrm{p}<0,0001)$. In the polluted stand the length of low and upper parts didn't differ essentially (52\% against 48\% at $\mathrm{p}<0.2300$ ). It can be suggested that in health pine trees the activity assimilate flows in stem was higher in comparison with inhibited trees, and it increases the diffusion of fungal metabolites towards roots.

\section{CONCLUSIONS}

The experiments carried out confirmed the possibility to reveal the difference of tree's condition in pine forest through inducing defence response in conducting tissues of trees. The both agents provoking hypersensitive reactions that we used could provide pronounced difference on length of necrosis in trees of different conditions. However, our results showed that using C. laricicola mycelium for inducing defence response might be difficult for deficiency of our knowledge about interrelations between the fungus and tree. Studies on the subject have to be continued to use the fungus for effective estimation of tree's conditions.

By contrast, the extract from $C$. laricicola mycelium seems to be the more proper as an inducing agent. Its advantages can be listed as follows:

1. hypersensitive reaction induced by fungal metabolites is less susceptible to influence of accidental factors;

2. the size of necrosis are more stable and more suitable for development of estimation scale;

3. the application of fungal extract allows to control its dose;

4. the application of the extract excludes the risk of spreading infection in weakened forests.

\section{REFERENCES}

Bach M. and H. U. Seitz 1997 Elicitor-induced defence responses of a suspension-cultured woody plant (Larix decidua) and possible mechanisms of signal transduction. Can. J. Bot., 75(8): 1243-1251

Cook S. P. and F. P. Hain 1987 Four parameters of the wound response of loblolly and short leaf pines to inoculation with the blue-staining fungus associated with the southern pine beetle. Can. J. Bot., 65(11): 2403-2440
Darvill A. G. and P. Albersheim 1984 Phytoalexins and their elicitors - a defense against microbial infection in plants. Annu. Rev. Plant Physiol., 35: 243-275

Leiutier F. and A. Berryman 1988 Preliminary histological investigations of the defense reactions of three pines to Ceratocystis clavigera and two chemical elicitors. Can. J. For. Res., 18(10): 1243-1247

Michajlova T. A. 1984 Physiological and biochemical changes at coniferous plants caused by action of hydrogen fluoride. Izv. Acad. Nauk USSR, Ser. Biol., 18(3): 74-80 (In Russian)

Miller R. H., A. A. Berryman and C. A. Ryan 1986 Biotic elicitors of defence reactions in lodgepole pine. Phytochemistry, 25(3): 611-612

Ozeretskovskaya O. L., G. V. Leont'eva, I. G. Romenskaya, G. I. Tshalenko, E. A. Perehod, T. M. Melnikova and A. I. Usov 1995 Xyloglucan-derived oligosaccharide fragments as the regulators of defence responses in potato tubes. Russian J. Plant Physiology, 42(5): 773-779

Pashenova N. V., A. A. Revenko, G. G. Polyakova and N.-S. Cho 2003 Studying adaptation of blue stain fungi to conifer species. In: 2003 Proc. of the 4th International Symposium on New Horizon of Bioscience in Forest Products Field, Cheongju (Korea). Chungbuk Nat. Univ, 190-199

Pashenova N. V., V. P. Vetrova, E. N. Aphanasova and M. Y. Konstantinov 2000 The blue stain fungi in living conifers. In: 2000 Proc. of the Korean Society of Wood Science and Technology, Annual Meeting, Seoul (Korea). Seoul: KSWST: 8-19

Polyakova G. G., N. V. Pashenova, V. P. Vetrova, V. V. Stasova, G. K. Zrazevskaya, I. V. Shein and M. Yu. Konstantinov 2000 Perspectives of using blue-stain fungi for assessment of conifer tree vigour and resistance to insects-vectors and associated pathogens. In: 2000 Proc. of the 2nd International Symposium on New Horizon of Bioscience in Forest Products Field, Cheongju (Korea). Chungbuk Nat. Univ, 26-42

Primoz O. 1999 Odziv drevesnih tkiv na poskodbe in infekcijo. 2. Kambijeva cona. Zb. Gozd. In les., 58: 189-217 (in Slovenian)

Reid R. W. and H. S. Whitney and J. A. Watson 1967 Reactions of lodgepole pine to attack by Dendroctonus ponderosae Hopkins and blue stain fungi. Can. J. Bot., 45: 1115-1126

Rozkov A. S. and T. A. Mikhajlova 1989 The effect of fluorine containing emissions on conifers. Novosibirsk: Nauka, 158. (in Russian)

Shein I. V., G. G. Polyakova, G. K. Zrazevskaya, N. V. Pashenova and V. P. Vetrova 2001 Accumulation of phenolic compound in conifer callus cultures in response to wood of blue stain fungi. Russian J. Plant Physiology, 48 (2): 251-256

Solheim H. 1993 Ecological aspects of fungi associated with the spruce bark beetle Ips typographus in Norway. In: Ceratocystis and Ophiostoma. M. J. Wingfield, K. A. Seifert and J. F. Webber. Eds. St. Paul, Minnesota: APS PRESS. 235-242

Stasova V. V. G. G. Polyakova, I. V. Shein and N. V. Pashenova 2003 Structural and metabolic change in Scotch pine phloem in response to injure and fungus infection. In: 2003 Proceedings XI Congress of Russian Botanical Society on Botanical researches in Asian Russia. Barnaul: Altaj State University, 2: 271-272 (In Russian)

Tatarintsev A. I. and L. N. Skripalshikova 2003 Pine phytocenosis in a zone of long-term influence of antropogeneous loadings. Geography and Natural Rresources, 3: 53-56 (In Russian)

Wong B. L. and A. A. Berryman 1977 Host resistance to the engraver beetle. 3. Lesion development and containment of infection resistant Abies grandis inoculated with Trichosporium symbioticum. Can. J. Bot., 55: 1358-1365

Yang D., R. S. Jeng and M. Hubbes 1989 Mansonone accumulation in elm callus induced by elicitors of Ophiostoma ulmi, and general properties of elicitors. Can. J. For. Res., 67(12): 3490-3497 